ORIGINAL ARTICLE

\title{
QTL detection for milk production traits in goats using a longitudinal model
}

\author{
D.L. Roldán ${ }^{1}$, A.E. Rabasa ${ }^{2}$, S. Saldaño ${ }^{2}$, F. Holgado ${ }^{3}$, M.A. Poli ${ }^{1}$ \& R.J.C. Cantet ${ }^{4}$ \\ 1 Instituto de Genética, CICVyA-INTA, CC 25 CP: 1712, Castelar, Provincia de Buenos Aires, Argentina \\ 2 FAZ-CONICET, UNT, Tucumán, Argentina \\ 3 CER Leales INTA, Tucumán, Argentina \\ 4 Dpto. Producción Animal, FA-UBA, Buenos Aires, and CONICET, Argentina
}

\section{Keywords}

Goats; lactation curve; quantitative trait loci.

\section{Correspondence}

M.A. Poli, Instituto de Genética, CICVyA-INTA, CC 25 CP: 1712, Castelar, Provincia de

Buenos Aires, Argentina. Tel: 5411 44500805; Fax: 5411 44500805;

E-mail: mpoli@cnia.inta.gov.ar

Received: 6 June 2006;

accepted: 7 November 2007

\section{Summary}

Eight paternal half-sib families were used to identify chromosomal regions associated with variation in the lactation curves of dairy goats. DNA samples from 162 animals were amplified by PCR for 37 microsatellite markers, from Capra hircus autosomes CHI3, CHI6, CHI14 and CHI20. Milk samples were collected during 6 years, and there were 897 records for milk yield (MY) and 814 for fat (FP) and protein percentage (PP). The analysis was conducted in two stages. First, a random regression model with several fixed effects was fitted to describe the lactation function, using a scale $(\alpha)$ plus four shape parameters: $\beta$ and $\gamma$, both associated with a decrease in the slope of the curve, and $\delta$ and $\phi$ that are related to the increase in slope. Predictions of $\alpha, \beta, \gamma, \delta$ and $\phi$ were regressed using an interval mapping model, and $F$-tests were used to test for quantitative trait loci (QTL) effects. Significant $(\mathrm{p}<0.05)$ QTLs were found for: (i) MY: CHI6 at 70-80 cM for all parameters; CHI14 at $14 \mathrm{cM}$ for $\delta$ and $\phi$; (ii) FP: CHI14, at $63 \mathrm{cM}$ was associated with $\beta$; CHI20, at $72 \mathrm{cM}$, showed association with $\alpha$; (iii) PP: chromosomal regions associated with $\beta$ were found at $59 \mathrm{cM}$ in CHI3 and at $55 \mathrm{cM}$ in CHI20 with $\alpha$ and $\gamma$. Analyses using more families and more animals will be useful to confirm or to reject these findings.

\section{Introduction}

Most studies of quantitative trait loci (QTL) detection for milk production traits have been carried out in cattle, using mostly aggregated data (Zhang et al. 1998; Heyen et al. 1999; Plante et al. 2001; Viitala et al. 2003; Ashwell et al. 2004). Genetic associations between molecular markers and economically important traits in goats have been reported by Cano et al. (2007) and Marrube et al. (2007). However, the only well-documented genetic association with dairy traits in goats is the one related with the highly variable alpha Sl-casein polymorphisms (Grosclaude et al. 1994; Adnoy et al. 2003; Manfredi 2003; Suárez 2004; Sacchi et al. 2005). Analyses on QTLs affecting milk traits of dairy goats are lacking.

In searching for QTLs in goats, one may look at those significant associations found between milk production traits and genetic markers in cattle (reviewed by Khatkar et al. 2004), and take advantage of the homology between the genetic maps of the cow and the goat. Moreover, Rodriguez-Zas et al. (2002) measured the association between chromosomal regions and the scale and shape that describe the lactation curve in dairy cattle using a two-stage procedure: a random regression model to predict the 
elements of the lactation function on an animal basis, followed by a regression interval mapping using the predictions obtained in the first stage of the analysis. The goal of this research was to identify chromosomal regions associated with variation in the lactation function of goats using the two-stage procedure employed by Rodriguez-Zas et al. (2002).

\section{Material and methods}

Description of phenotypic data

The population used in the study was established in 1998 at the Regional Experimental Center of Leales - INTA, in the province of Tucumán, Argentina. Phenotypes recorded were milk yield (MY), fat percentage (FP) and protein percentage (PP) from 212 female goats. Milk samples were collected at the morning milking, at each of the two kidding seasons (fall-winter and spring-summer) during 6 years (1999-2004). Each goat was sampled for FP and PP once a month, either five or six times per lactation. Records of daily MY for a given test day were the averages of an entire week, with sampling taking place every month but on an irregular basis (up to 3 weeks a month). Lactations with three or fewer records were deleted, and the lactation stage ranged from 3 to 321 days. The total number of observations were 897 for MY, and 814 for FP and PP. Averages (standard deviations) across all families were $0.879 \mathrm{~kg}$ (SD 0.563) for MY, 4.382\% (SD 1.864) for FP and $4.065 \%$ (SD 0.757) for PP.

\section{Genotypic data}

Eight paternal half-sib families composed of 87 young females and 75 older goats were used for QTL detection. Whereas six families were purebred Criollo goats, the two other families consisted of Saanen by Criollo crosses. The Criollo goat is a local dairylike breed living in harsh environments. The breed has remained almost unselected since its introduction from Spain nearly 500 years ago (Rodero et al. 1992). The number of females recorded for MY and FP or PP, and the number of genotyped goats per family are displayed in Table 1 .

DNA was extracted from whole blood using the technique by Madisen et al. (1987). PCR reactions were carried out using fluorescence or $\gamma{ }^{32} \mathrm{P}$ ATPprimers labels as previously described by Cano et al. (2007), and the PCR products were separated by electrophoresis in denaturing polyacrylamide gels, and visualized in an automatic sequencer or in autoradiography. We selected four Capra hircus auto-
Table 1 Breed composition, number of recorded goats, total number of records and number of genotyped goats per half-sib family

\begin{tabular}{|c|c|c|c|c|c|}
\hline \multirow[b]{2}{*}{ Families } & \multirow{2}{*}{$\begin{array}{l}\text { Breed } \\
\text { composition }\end{array}$} & \multirow{2}{*}{$\begin{array}{l}\text { Number of } \\
\text { recorded } \\
\text { goats }\end{array}$} & \multicolumn{2}{|c|}{$\begin{array}{l}\text { Total number } \\
\text { of records }\end{array}$} & \multirow{2}{*}{$\begin{array}{l}\text { Number of } \\
\text { genotyped } \\
\text { goats }\end{array}$} \\
\hline & & & MY & Contents & \\
\hline 1 & Criollo & 30 & 114 & 112 & 25 \\
\hline 2 & Criollo & 22 & 92 & 83 & 16 \\
\hline 3 & Criollo & 26 & 107 & 91 & 25 \\
\hline 4 & Criollo & 23 & 99 & 93 & 18 \\
\hline 5 & Criollo & 19 & 78 & 67 & 15 \\
\hline 6 & Criollo & 16 & 46 & 34 & 7 \\
\hline 7 & Saanen cross & 20 & 85 & 74 & 14 \\
\hline 8 & Saanen cross & 56 & 276 & 260 & 42 \\
\hline Total & - & 212 & 897 & 814 & 162 \\
\hline
\end{tabular}

MY, milk yield.

somes (CHI), based on the homologies between the genetic maps of cattle and goats and the significant associations summarized by Khatkar et al. (2004) in Bos taurus autosome (BTA) 3, 6, 14 and 20.

A total of 37 microsatellite markers (MS) were selected from the web genetic map resources (http://locus.jouy.inra.fr/cgi-bin/lgbc/mapping/common/ intro2.pl?BASE = goat, http://locus.jouy.inra.fr/cgibin/lgbc/mapping/common/intro2.pl?BASE = cattle, http://www.animalgenome.org/cattle/maps/db.html and http://bioinformatics.roslin.ac.uk). The linkage maps were used as a guide for intermarker distance, and the microsatellites were positioned and ordered on the chromosomes with the CRI-MAP 2.4 program (Green et al. 1990). A summary of the informative markers used in the study across the four chromosomes are shown in Table 2. The average number of informative markers by autosome was 6 (ranging from 4 to 8 ), with an average spacing of $19.22 \mathrm{cM}$. The highest proportion of heterozygous sires averaged over all markers by chromosome was in CHI6. The average heterozygosity was $60.72 \%$, and the average number of alleles by marker across families was 6.7. The markers showing the highest polymorphic information content (PIC) were microsatellites BM4621, BMl43 and CSN, with PIC values of 0.798 , 0.789 and 0.763 , respectively, and located in CHI6.

\section{Statistical analysis}

The analysis was conducted in two stages. We first calculated the predictions of the random regression coefficients, and then we tested the effects of the chromosome regions on those predictions. The random regression model used in the first stage included the goat-specific parameters plus the predictions of 
Table 2 A summary of the informative markers used across chromosomes

\begin{tabular}{cllll}
\hline & $\begin{array}{l}\text { Number } \\
\text { of } \\
\text { markers }\end{array}$ & PIC & $\begin{array}{l}\text { Proportion of } \\
\text { heterozygous } \\
\text { sires }^{\text {a }}\end{array}$ & Marker distances (CM) \\
\hline 3 & 4 & 0.604 & 0.50 & INRA006 (0.0), MCM58 (23.4), INRA023 (29.7), HUJ177 (17.5) \\
6 & 5 & 0.665 & 0.62 & BM1329 (0.0), BM143 (31.7), BM4621 (34.4), BM415 (23.3), CSN (42.3) \\
14 & 8 & 0.511 & 0.58 & ETH225 (0.0), ILSTS011 (9.4), RM011 (26.8), CSSM66 (17.8), CSSM36 (9.1), \\
& 7 & & & BMC1207 (20.4), BM302 (36.5), BM4513 (38.8) \\
& 0.516 & 0.43 & TGLA304 (0.0), TGLA443 (6.4), BM4107 (17.2), INRA036 (17.6), OarHH62 (13.2), \\
& & & ILSTS072 (10.9), BMS1719 (7.1) \\
\hline
\end{tabular}

$\mathrm{CHI}$, Capra hircus autosome; PIC, polymorphic information content.

${ }^{\text {a }}$ Proportion of heterozygous sires averaged over all markers by chromosome.

individual breeding values and permanent environmental effects. The model equation was as follows:

$$
\begin{aligned}
y_{i j h r s}= & c_{l}+b_{n}+d_{r}+p_{s}+\sum_{m=1}^{5} \kappa_{n s m} \varphi(t)_{m} \\
& +\sum_{m=1}^{5} \psi_{i n m} \varphi(t)_{m}+\sum_{m=1}^{5} \tau_{i m} \varphi(t)_{m} \\
& +\sum_{m=1}^{5} \pi_{i m} \varphi(t)_{m}+\varepsilon_{i j h r s}
\end{aligned}
$$

In Eqn. (1), $y_{i j h r s}$ is the record of MY, FP, or PP, for the $i$ th animal measured on the jth test-day taken on year $l(l=1999, \ldots, 2004)$, under lactation number $n$ $(n=1, \ldots, 6)$, with the $r$ th number of kids at parturition $(r=1,2)$, and in the sth season $(s=$ fall-winter, spring-summer). Fixed effects in the model were year $\left(c_{l}\right)$, lactation number $\left(b_{n}\right)$, number of kids at parturition $\left(d_{r}\right)$, and season $\left(p_{s}\right)$. Additionally, the parameters of the regression function of Ali \& Schaeffer (1987) were fitted for each combination of lactation and season $\left(\kappa_{n s m}\right)$. The regression coefficients $\left(\psi_{\text {inm }}\right)$ in the Ali \& Schaeffer (1987) function were also fitted as random variables that are associated with the permanent environmental effects that are common to the $n$th lactation number. For animal $i$, the random variables $\tau_{i m}$ and $\pi_{i m}$ are the regression coefficients for the breeding values and the permanent environmental effects, respectively, of the lactation curve proposed by Ali \& Schaeffer (1987). For animal $i$ measured on day $j$, the random regression function which mimics the model of Ali \& Schaeffer (1987) can be written as

$$
\begin{aligned}
\sum_{m=1}^{5} \lambda_{i j m} \varphi\left(t_{i j}\right)= & \alpha_{i}+\beta_{i}\left(\frac{t_{i j}}{280}\right)+\gamma_{i}\left(\frac{t_{i j}}{280}\right)^{2}+\delta_{i} \ln \left(\frac{280}{t_{i j}}\right) \\
& +\phi_{i}\left[\ln \left(\frac{280}{t_{i j}}\right)\right]^{2}
\end{aligned}
$$

where $\lambda_{i j m}$ is either $\tau_{i j m}$ or $\pi_{i j m}$, and $t_{i j}$ is the $j$ th testday for animal $i$. The scale parameter that character- izes the overall level of the trait (MY, FP or PP) for the curve of individual $i$ is $\alpha_{i}$. The remaining parameters are responsible for the shape of the curve, and represent the rate of change of the trait at different stages of the lactation: $\beta_{i}$ and $\gamma_{i}$ are associated with a decreasing slope of the curve, and $\delta_{i}$ and $\phi_{i}$ with increasing slope. The lactation length was taken to be 280 days. The variance and covariance functions in the random regression model (1) were estimated by Restricted Maximum Likelihood using the program VCE5 (Kovac \& Groeneveld 2003). The permanent environmental matrix $(E)$ was estimated with a submodel of (1) in which the fifth and sixth terms were left out. To fit (1), $E$ was split into 'across lactations' $\left(E_{\mathrm{B}}\right)$ and 'within lactation' $\left(E_{\mathrm{W}}\right)$ components, such that $E_{\mathrm{W}}=0.4 E$ and $E_{\mathrm{B}}=(1-0.4) E$. The value 0.4 corresponds to the correlation between permanent environmental effects of first and second lactations. The estimates of the fixed effects, as well as of the additive genetic and permanent environmental effects were calculated by solving the mixed model equations using a program written in PROC IML (SAS Institute Inc 2005).

In the second stage, we performed a QTL analysis using the half-sib regression interval mapping method of Knott et al. (1996), with the software QTL Express (Seaton et al. 2002). The test statistics were computed every centiMorgan over the mapped chromosome. F-statistic thresholds for chromosome-wise level were calculated from 10000 permutations (Churchill \& Doerge 1994). Families that displayed the highest evidence for a QTL at the location in the across-family analysis were taken from the QTLexpress output (Knott et al. 1996).

\section{Results and discussion}

The estimated heritability for MY ranged from 0.142 to 0.593 , and the average estimated over the whole lactation period was 0.343 . These values were in 
agreement to those reported in the literature for different goat breeds, and with estimates obtained from either single or multiple trait models. Our results seem to be slightly lower than those of Weppert $\delta$ Hayes (2004) for Nubian, Alpine, Saanen and Toggenburg goats, when maternal effects were included in the analysis. The estimated heritability of MY from a model without maternal effects was equal to 0.19 (Weppert \& Hayes 2004). Similar estimates of heritability to the values found in the current study were reported for South African Saanen goats (0.30, Muller et al. 2002), and for Alpine and Saanen females (0.23, Clément et al. 2002).

The average heritability estimate of FP was equal to 0.092 (ranging from 0.093 to 0.141 ), and the average heritability estimate of PP was 0.160 (ranging from 0.007 to 0.515$)$. These values were lower than those obtained and reviewed by Muller et al. (2002) using data from several goat breeds: the range of FP was 0.160-0.540 (Spain, Alpine, Saanen and Toggenburg breeds) and the range of PP was 0.250-0.620 (Spain, Greece and Saanen goats).

For the QTL analysis, all significant F-statistics and their $\mathrm{p}$-values for the three traits obtained from the regression interval mapping method of Knott et al. (1996) are displayed in Table 3.

\section{Milk yield}

Seven tests were significant for at least one parameter. In CHI6, we detected a significant effect for all parameters in the interval flanked for the MS

Table 3 F-statistics and p-values for the significant marker associations in at least one parameter of the lactation function for each milk production trait

\begin{tabular}{llllll}
\hline & & & Map position & $\begin{array}{l}\text { F-statistics } \\
\text { (p-values) }\end{array}$ & Family \\
\hline 3 & Traits & $\lambda^{\text {a }}$ & (cM) & $2.99(0.01205)$ & $5 / 7$ \\
6 & PP & $\beta$ & 59 & $4.35(0.00016)$ & 7 \\
6 & MY & $\alpha$ & 75 & $4.89(0.00004)$ & 7 \\
6 & MY & $\beta$ & 78 & $4.38(0.00016)$ & 7 \\
6 & MY & $\gamma$ & 75 & $3.48(0.00146)$ & 7 \\
6 & MY & $\delta$ & 71 & $3.20(0.00293)$ & 7 \\
14 & MY & $\phi$ & 70 & $2.35(0.04062)$ & 7 \\
14 & MY & $\delta$ & 14 & $2.42(0.03559)$ & 7 \\
14 & MY & $\phi$ & 14 & $2.63(0.01300)$ & 6 \\
20 & FP & $\beta$ & 63 & $4.49(0.00056)$ & 5 \\
20 & PP & $\alpha$ & 55 & $4.56(0.00049)$ & 5 \\
20 & PP & $\gamma$ & 55 & $4.71(0.00034)$ & 5 \\
\hline
\end{tabular}

MY, milk yield; FP, fat percentage; PP, protein percentage. aparameters of the lactation function. $\alpha$, scale parameter; $\beta$ and $\gamma$, decreasing slope; $\delta$ and $\phi$, increasing slope.
BM4621 and BM415 (from 70 to $78 \mathrm{cM}$ ). One chromosomal region was associated with $\delta$ and $\phi$ on CHI14. Several studies based on cumulative single records in dairy cattle detected the presence of QTL at the genome-wise and suggestive thresholds on BTA3, in the interval from 16 to $32 \mathrm{cM}$ (Heyen et al. 1999), at $39 \mathrm{cM}$ (Plante et al. 2001), and at $40 \mathrm{cM}$ (Vandervoort \& Jansen 2002). On the other hand, neither Viitala et al. (2003) nor Ashwell et al. (2004), reported evidence of a QTL for MY on BTA3. Rodriguez-Zas et al. (2002) using test-day milk records reported a significant association between marker MS BL41 (32 cM) and the parameter that describes the shape of the function at the beginning of the lactation. Additionally, these workers reported significant associations between the scale parameter and two chromosomal regions of BTA3 that were located in the centromere from 0 to $36 \mathrm{cM}$ and in the telomere from 91 to $113 \mathrm{cM}$ (close to MS HUJI177 at $100 \mathrm{cM}$ and MS BR4502 at $113 \mathrm{cM})$.

An association with increasing slope parameters $\delta$ and $\phi$ was found at 70 and $71 \mathrm{cM}$, respectively, on CHI6. Also at $75 \mathrm{cM}$, the scale parameter $(\alpha)$ and the descriptor of the shape at the end of the lactation $(\gamma)$ were found to be significant. Another association with the remained descriptor of the decreasing slope $(\beta)$ was detected at $78 \mathrm{cM}$. The correlation between the estimates of $\alpha, \gamma, \delta$ and $\phi$ was high (0.922$0.998)$. Similarly, the correlation between $\beta$ and the other parameters ranged from 0.652 to 0.758 . Such correlations may suggest a QTL with pleiotropic effects on these parameters. Rodriguez-Zas et al. (2002) detected a putative QTL between 0 and $21 \mathrm{cM}$ in dairy cattle that affected the scale parameter for MY. They also reported the finding of another QTL affecting the shape parameters for MY, which is located in the region from 108 to $129 \mathrm{cM}$. In dairy cattle, Zhang et al. (1998) reported a putative QTL in the interval between 30 to $50 \mathrm{cM}$ on BTA6 (between MS BM1329 and BM143).

In the goat, the casein gene cluster has been mapped to the distal region of CHI6 (Grosclaude et al. 1994), and is composed of four genes ( $\alpha \mathrm{Sl}$ casein, $\alpha$ S2-casein, $\beta$-casein, and $\kappa$-casein). Moioli et al. (2007) reviewed the several associations between casein genes, and dairy traits of goats have been reported in the literature. This is especially so for the $\alpha \mathrm{S}$ l gene, which displays a higher level of polymorphism than the one observed in the bovine, and has been related to fat and protein contents (Grosclaude et al. 1994; Adnoy et al. 2003; Manfredi 2003; Sacchi et al. 2005). However, the effect of $\alpha$ S 1 casein alleles on MY does not seem to be important 
(Moioli et al. 2007). In the current research, we used $\alpha \mathrm{S} 1$ casein gene as a marker gene (MS CSN) and did not find association to MY. A QTL on chromosome 6 of cattle located closer to the casein gene cluster was reported by Khatkar et al. (2004).

Moving to CHI14, there was evidence for a QTL at $14 \mathrm{cM}$ (the interval flanked by ILSTS0ll and RM011) related to $\delta$ and $\phi$. This result suggests that there may be a QTL with pleiotropic effects on both parameters. It may also be the case that, due to the high correlation (0.996) between the estimates of those parameters, one of the associations observed may be a false positive. Similarly, Rodriguez-Zas et al. (2002) reported an association between the chromosomal region at about $13 \mathrm{cM}$ on BTAl4 (marker CSSM66), and the shape parameters that describe the changes in milk yield during mid and late lactation. However, in dairy cattle a QTL affecting MY was seemingly associated with BTA14 by Khatkar et al. (2004). Several studies in cattle reported QTLs for MY on BTA20. The chromosomal regions in the bovine were at $21 \mathrm{cM}$ (Plante et al. 2001), $82 \mathrm{cM}$ (Viitala et al. 2003) and 68 cM (Ashwell et al. 2004). In the current study, no microsatellite marker on CHI20 was associated with some lactation descriptors.

\section{Fat percentage}

Although several studies in dairy cattle reported a putative QTL on BTA3 and BTA6 affecting FP (Khatkar et al. 2004), we did not find evidence for the effects of a chromosomal region in either $\mathrm{CHI} 3$ or CHI6, at the chromosomal-wise threshold. However, for FP we detected significant effects from CHIl4 and CHI20.

When analyzing $\mathrm{CHI} 14$, one chromosomal region at 63 cM (between CSSM66 and CSSM36) associated with variation of the parameter $\beta$ was found significant. Conversely, analyses with dairy cattle found strong evidence for a putative QTL affecting FP near the centromere of BTAl4, being the MS CSSM66 the nearest marker (Coppieters et al. 1998; Zhang et al. 1998; Heyen et al. 1999; Ashwell et al. 2004). A QTL proximal to the centromere on BTAl4 with an effect on FP has consistently been reported (Grisart et al. 2002 and Winter et al. 2002), and the mutation underlying this QTL has been identified (Winter et al. 2002) as the K232A substitution in exon VIII of acylCoA/diacylglycerol acyltransferase 1 enzyme (DGAT1). This enzyme is considered to be of importance in controlling the synthesis rate of triglycerides in adipocytes. Nevertheless, no associations with several microsatellite markers on BTAl4 were found by Rodriguez-Zas et al. (2002) using a longitudinal mapping model. Comparing the goat and bovine linkage maps, CHIl4 shows a partial homology with BTAl4 from MS CSSM66 to the telomere. The centromeric region of $\mathrm{CHI} 44$ flanked between MS ETH225 and MS BM757, corresponds to the same region of chromosome 9 in cattle. Therefore, it is likely that an association with FP could be found near the centromeric end of CHI9.

At $72 \mathrm{cM}$ on CHI20, where the nearest marker is BMS1719, we detected an association with $\alpha$ $(\mathrm{p}<0.00002)$. Many additional QTL with significant effects on FP and FY has been reported for chromosome 20 in dairy cattle (Khatkar et al. 2004).

\section{Protein percentage}

Chromosomal regions associated with $\beta$ for PP were found in $\mathrm{CHI} 3$. For this chromosome and close to MS INRA023 (at 59 cM), we detected a chromosomal region affecting $\beta$. A QTL for PP located in an area of about $40 \mathrm{cM}$ in BTA3 was reported in several studies (Khatkar et al. 2004).

We did not find significant associations among chromosomal regions of CHI6 and any parameter when looking at PP. Nevertheless, many studies in dairy cattle have detected the presence of a QTL close to MS BM143 in BTA6 that is related to PP, and the marker position agrees in all these studies (Spelman et al. 1996; Zhang et al. 1998; Ron et al. 2001; Viitala et al. 2003). Using longitudinal phenotypic data, Rodriguez-Zas et al. (2002) found significant association between MS BM143 and the scale and the shape parameters at middle and late lactation for PP in dairy cows. Recently, Schnabel et al. (2005) performed a fine-mapping study of BTA6 of dairy cattle and identified the osteopontin (OPN) gene as an ideal functional candidate gene for a QTL very close to BM143. The $O P N$ is a secreted glycoprotein and its expression in the murine mammary gland depends on the stage of postnatal development, which in turn suggests a role for $O P N$ in mammary involution.

\section{Lactation patterns}

We use the expression longitudinal mapping model to refer to those statistical models for mapping QTLs of a longitudinal (or functional value) trait. The ability of the model used in the current study to detect associations between markers and lactation stages may contribute to explain the different lactation patterns among individuals. 
Although breeders do not usually breed for lactation shape, some traits such as persistence that are described by lactation curve parameters are economically relevant. We have looked at MY persistency. However, we did not find any significant association with any of the markers studied here.

\section{General}

Although the function of Ali $\&$ Schaeffer (1987) may suffer from high correlations among the five predicted parameters, Macciota et al. (2005) observed that certain combinations in the signs of the parameters were more prone to a high correlation than others. For the correlation patterns observed among the five predicted parameters ranged from 0.658 (correlation between $\beta$ and $\phi$ ) to 0.998 (correlation between $\alpha$ and $\gamma$ ). The function of Ali \& Schaeffer (1987) is flexible as it allows accounting for differences in the rate of change in milk along the entire lactation, thus displaying a large number of different curves as described by Macciota et al. (2005).

A limitation of this study is the less number of animals involved in the analysis, which was coupled with a limited size of the half-sib families involved. Clearly, these results have low statistical power. Even if the results are not conclusive, they provide, nevertheless, a general idea of potential QTL locations in Criollo and Creole cross goats. Analyses using more families and more animals will be useful to confirm or to reject our findings.

To our knowledge, this is the first report in goats searching for chromosomal regions associated with variation in the lactation curve. Nine map positions were identified as affecting any parameter of the lactation function of dairy goats: one in $\mathrm{CHI} 3$, four in CHI6, two in CHIl4 and two in CHI20. Some of these results were consistent with QTLs found in dairy cattle while using either aggregate lactation records, or longitudinal-linkage analysis.

\section{Acknowledgements}

The authors thank SeCyT-ANPCyT, Argentina, through the National Project BID1728 PICTO12968, Universidad de Buenos Aires, through grants UBACyT G018-Program 2004-2007 and CONICET PIP 5338 2006-2007; La Serenísima S.A., Argentina, for their cooperation in supplying compositional milk data. We would also like to thank two anonymous reviewers for their constructive comments and suggestions that greatly enhanced the presentation.

\section{References}

Adnoy T., Vegarud F., Gulbrandsen T., Nordblo R., Colbjorsen I., Brovold M., Markovic B., Roseth A., Lien S. (2003) Effects of the O and F alleles of alpha S1 casein in two farms of northern Norway, International Workshop on Major Genes and QTL in Sheep and Goats, Toulouse, France, 8-11 December 2003. CD Comm. 2-20.

Ali T.E., Schaeffer L.R. (1987) Accounting for covariances among test day milk yields in dairy cows. Can. J. Anim. Sci., 67, 637-644.

Ashwell M.S., Heyen D.W., Sonstegard T.S., Van Tasell C.P., Da Y., VanRaden P.M., Ron M., Weller J.I., Lewin H.A. (2004) Detection of quantitative trait loci affecting milk production, health, and reproductive traits in Holstein cattle. J. Dairy Sci., 87, 468-475.

Cano M., Marrube G., Roldán D., Bidinost F., Abad M., Allain D., Vaiman D., Taddeo H., Poli M. (2007) QTL affecting fleece traits in Angora goats. Small Rum. Res., 71, 159-164.

Churchill G.A., Doerge R.W. (1994) Empirical threshold values for quantitative trait mapping. Genetics, 138, 963-971.

Clément V., Boichard O., Piacere A., Barbat A., Manfredi E. (2002) Genetic evaluations of French goats for dairy and type traits, Proceedings of the 7th World Congress on Genetics Applied Livestock Production, Montpellier, France, 19-23 August 2002. Comm. 1-46.

Coppieters W., Riquet J., Arranz J., Berzi P., Cambisano N., Grisart B., Karim L., Marcq F., Moreau L., Nezer C., Simon P., Vanmanshoven P., Wagenaar D., Georges M. (1998) A QTL with major effect on milk yield and composition maps to bovine chromosome 14. Mamm. Genome, 9, 540-544.

Green P., Falls K., Crooks S. (1990) Cri-map Documentation Version 2.4. Washington University School of Medicine, St Louis, MO. Available at http://linkage. rockefeller.edu/soft/crimap/.

Grisart B., Coppieters W., Farnir F., Karim L., Ford C., Berzi P., Cambisano N., Mni M., Reid S., Simon P., Spelman R., Georges M., Snell R. (2002) Positional candidate cloning of a QTL in dairy cattle: identification of a missense mutation in the bovine DGATl gene with major effect on milk yield and composition. Genome Res., 12, 222-231.

Grosclaude F., Martin P., Ricordeau G., Remeuf F., Vassal L., Bouillon J. (1994) Du gène au frommage: le polymorphisme de la caséine alpha-S1-caprine, ses effets, son évolution. INRA Prod. Anim., 7(Suppl. 1), 3-9.

Heyen D.W., Weller J.I., Ron M., Band M., Beever J.E., Feldmesser E., Da Y., Wiggans G.R., VanRaden P.M., Lewin H.A. (1999) A genome scan for QTL influencing milk production and health traits in dairy cattle. Physiol. Genomics, 1, 165-175. 
Khatkar M.S., Thomson P.C., Tammen I., Raadsma H.W. (2004) Quantitative trait loci mapping in dairy cattle: review and meta-analysis. Genet. Sel. Evol., 36, 163-190.

Knott S., Elsen J.-M., Haley C. (1996) Methods for multiple-marker mapping of quantitative trait loci in half-sib populations. Theor. Appli. Genet., 93, 71-80.

Kovac M., Groeneveld E. (2003) VCE-5. User's Guide and Reference Manual. Institute of Animal Science, Neustand-Germany.

Macciota N., Vicario D., Cappio-Borlino A. (2005) Detection of different shapes of lactation curve for milk yield in dairy cattle by empirical mathematical models.

J. Dairy Sci., 88, 1178-1191.

Madisen L., Hoar D.I., Holroyd C.D., Crisp M., Hodes M.E. (1987) DNA banking: the effects of storage of blood and isolated DNA on the integrity of DNA. Am. J. Med. Genetics., 27, 379-390.

Manfredi E. (2003) The tale of goat $\alpha$ sl-casein. International Workshop on Major Genes and QTL in Sheep and Goats, Toulouse, France, 8-11 December 2003. CD Comm. 2-17.

Marrube G., Cano M., Roldán D., Bidinost F., Abad M., Allain D., Vaiman D., Taddeo H., Poli M. (2007) QTL affecting conformation traits in Angora goats. Small Rumin. Res., 71, 255-263.

Moioli B., D'Andrea M., Pilla F. (2007) Candidate genes affecting sheep and goat milk quality. Small Rumin. Res., 68, 179-192.

Muller C.J.C., Cloet S.W.P., Schoeman S.J. (2002) Estimation of genetic parameters for milk yield and milk composition of South African Saanen goats. Proceedings of the 7th World Congress on Genetics Applied Livestock Production, Montpellier, France, 19-23 August 2002. Comm. 1-52.

Plante Y., Gibson J.P., Nadesalingam J., Mehrabani-Yeganeh H., Lefebvre S., Vandervoort G., Jansen G.B. (2001) Detection of quantitative trait loci affecting milk production traits on 10 chromosomes in Holstein cattle. J. Dairy Sci., 84, 1516-1524.

Rodero A., Delgado J.V., Rodero E. (1992) Primitive Andalusian livestocks and their implication in the discovery of America. Arch. Zoot., 41, 383-400.

Rodriguez-Zas S.L., Southey B.R., Heyen D.W., Lewin H.A. (2002) Detection of quantitative trait loci influencing dairy traits using a model for longitudinal data. J. Dairy Sci., 85, 2681-2691.

Ron M., Kliger D., Feldmesser E., Seroussi E., Ezra E., Weller J.I. (2001) Multiple quantitative trait locus analysis of bovine autosome 6 in the Israeli Holstein population by a daugther design. Genetics, 159, 727-735.

Sacchi P., Chessa S., Budelli E., Bolla P., Ceriotti G., Soglia D., Rasero R., Cauvin E., Caroli A. (2005)
Casein haplotype structure in five Italian goat breeds. J. Dairy Sci., 88, 1561-1568.

SAS Institute Inc, (2005) Statistical Analysis Systems. SAS, Cary, NC, USA.

Schnabel R.D., Kim J.J., Ashwell M.S., Sonstegard T.S., Van Tassell C.P., Connor E.E., Taylor J.F. (2005) Finemapping milk production quantitative trait loci on BTA6: Analysis of the bovine osteopontin gene. Proc. Natl. Acad. Sci., 102, 6896-6901.

Seaton G., Haley C., Knott S., Kearsey M., Visscher P. (2002) QTL Express: mapping quantitative trait loci in simple and complex pedigrees. Bioinformatics, 18, 339340.

Spelman R.J., Coppieters W., Karim L., van Arendonk J.A.M., Bovenhuis H. (1996) Quantitative trait loci analysis for five milk production traits on chromosome six in the Dutch Holstein-Friesian population. Genetics, 144, 1799-1808.

Suárez C.M. (2004) Polimorfismos en el gen CSN1S1 en caprinos Criollos de los valles Calchaquíes. Su distribución y efecto sobre caracteres de producción de leche. Tesis Magister en Biotecnología. Universidad Nacional de Buenos Aires, Buenos Aires, $66 \mathrm{p}$.

Vandervoort G., Jansen G.B. (2002) Comparison of QTL mapping models with multiple traits and multiple intervals in a halfsib design in dairy cattle. Proceedings of the 7th World Congress on Genetic Applied Livestock Production, Montpellier, France, 19-23 August 2002. CD Comm. 21-49.

Viitala S.M., Schulman N.F., de Koning D.J., Elo K., Virta A., Virta J., Mäki- Tanila A., Vilkki J.H. (2003) Quantitative trait loci affecting milk production traits in Finnish Ayrshire dairy cattle. J. Dairy Sci., 86, 1828-1836.

Weppert M., Hayes J.F. (2004) Direct genetic and maternal genetic influences on first lactation production in four breeds of dairy goats. Small Rumin. Res., 52, 173178.

Winter A., Krämer W., Werner F.A., Kollers S., Kata S., Durstewitz G., Buitkamp J., Womack J.E., Thaller G., Fries R. (2002) Association of a lysine-232/alanine polymorphism in a bovine gene encoding acylCoA:diacylglycerol acyltransferase (DGAT1) with variation at a quantitative trait locus for milk fat content. Proc. Natl. Acad. Sci., 99, 9300-9305.

Zhang Q., Boichard D., Hoeschele I., Ernst C., Eggen A., Murkve B., Pfister- Genskow M., Witte L.A., Grignola F.E., Uimari P., Thaller G., Bishop M.D. (1998) Mapping quantitative trait loci for milk production and health of dairy cattle in a large outbred pedigree. Genetics, 149, 1959-1973. 